\title{
DEVELOPMENT OF MEATCONTAINING PRODUCTS WITH A BALANCE OF FATTY ACIDS COMPOSITION
}

\section{Nataliia Bozhko ${ }^{1}$ \\ Vasyl Pasichnyi}

DOI: https://doi.org/10.30525/978-9934-588-15-0-53

Abstract. Correcting low consumption of $\omega-3$ and $\omega-6$ polyunsaturated fatty acids and reducing the total consumption of fats in the human diet to physiologically sound standards is an urgent task for nutritionists and food manufacturers. The solution to this problem is through the development and implementation of new combination meat products with a balanced amino acid and fatty acid composition (FAC). The aim of research was to study and analyze the biological performance of fats of meatcontaining combined products from cooked group with balanced FAC. Cooked group products have been used as a model to study the biological effectiveness of fats meatcontaining products with meat of waterfowl and freshwater fish to achieve this goal. It was boiled sausages with Muscovy duck meat, with duck meat and Carassius gibelio, meat bread with Muscovy duck meat and silver carp meat. The determination of nutritional value was carried out by the calculation method. The fatty acids profile (FAP) was determined in the test samples and the ratio of fatty acids (FA). The level of satisfaction of the recommended daily requirement was calculated. The conducted studies have confirmed that the lipids of the developed meatcontaining products of the boiled group are characterized by a high content of unsaturated, including essential, FA in their composition - linoleic, oleic, linoleic. The high content of MUFA C18:1 $\omega-9$ (oleic) was experimentally established in all developed products $-43,07-45,48 \mathrm{~g} / 100 \mathrm{~g}$ fat. It is experimentally proved that the significant content of $\omega$-3 PUFA, deficiency of which is characteristic for nutrition of the population of Ukraine, in the developed meatcontaining products of the cooked group $(0,21-0,39 \mathrm{~g} / 100 \mathrm{~g}$ of product) can satisfy

${ }^{1}$ Candidate of Agricultural Sciences, Associate Professor,

Sumy State University, Ukraine

${ }^{2}$ Doctor of Engineering Sciences, Professor,

Head of Meat Technology and Meat Products,

National University of Food Technology, Ukraine

(C) Nataliia Bozhko, Vasyl Pasichnyi 
the recommended daily requirement for essential FA by $28 \%$. It is determined that the ratio between individual families FA $\omega-3 / \omega-6$ in the developed products is from $1: 7$ to $1: 9,8$ at the recommended physiological norms of ideal fat food 1:5-1:10. Meatcontaining products of boiled groups made using Muscovy duck and freshwater aquaculture with such content and combination of PUFA can be recommended for nutrition of a healthy person. The above results suggest that the use of the proposed recipe solutions of meatcontaining combined products of the cooked group increase their nutritional value. It has been found that lipids of meatcontaining cooked products correspond to optimal values for most of the calculated biological efficiency indicators. Taking into account the systematized data on a wide range of clinical and pharmacological effects of $\omega-3$ and $\omega-6$ PUFA, it is possible to consider meatcontaining combined products of cooked group based on duck meat and freshwater aquaculture as a source of essential FA in the human diet and use them for recovery of lipid balance in the diets of the modern Ukraine population.

\section{Introduction}

With the increasing availability of information, there are more and more consumers in the world today who are interested in their diet and prefer a healthy lifestyle.

A balanced diet within the nutrition is one of the common food trends of the last few years. Customers prefer environmentally friendly products with a balanced low calorie composition, which requires efficient evaluation of the quality of these products [1, p. 79]. According to statistics, $78 \%$ of consumers are ready to pay 50-100\% more for natural, healthy foods [2, p. 42].

Development of new modern products with increased nutritional and biological value becomes an urgent problem for food producers. In the current situation, an important factor in the adjustment of the diet is combined products created on the basis of the plant and animal raw materials combination, taking into account the physiological needs of the human body.

One of the key solutions of this problem is the development and implementation of specialized foods with balanced FAC. Nowadays there is a violation of the nutritional status of the population in Ukraine [3, p. 6].

Animal fats predominate in diets, that characterized by the dominant content of saturated FA and deficiency of essential PUFA. Lipids are one of 
the important and necessary components of the modern human diet, which provide the body with the energy needed for metabolism, act as a regulator of metabolic processes, and are structural elements of the membranes of all cells $[4$, p. 4].

For this reason the content of lipids in food, their composition and the ratio of individual classes are given special attention.

The combination of raw materials with different origins in the formation of multicomponent foods can help to increase the biological efficiency of their lipids.

One of the problems of creating multicomponent products is the fat imbalance by the main fatty acid indicators, the main of which are the ratio of saturated (SFA), monounsaturated (MUFA) and polyunsaturated fatty acids (PUFA), should be 1:1:1 and the PUFA ratio $\omega-6: \omega-3$, which ideally should be $9 . . .10: 1[5$, p. 15].

Therefore, the topical question today is the correct ratio of PUFA and the quantitative provision of human body PUFA $\omega-6$ and $\omega-3$, the lack of which leads to inhibition of growth in children, decreased immunity, impaired water metabolism, slow healing of wounds and can lead to cirrhosis, kidney damage, infertility [6, p. 9].

\section{Literature review and problem statement}

The most important chemical characteristic of lipids is the FA composition. Based on the obtained data [7, p. 15; 8, p. 67], the FA classification is proposed, according to which four classes of FA are distinguished: essential (oleic, linoleic, arachidonic, linolenic, docosahexaenoic), nonessential (stearic, palmitic, myristic), anti-alimentary (saturated and monounsaturated (more than 20)) and toxic (acetylene with triple bonds) FA, oxyacids, acyclic (with 5 or 3 membered cycles in the radical) FA.

According to the concept of an ideal fat diet, the fat component of the daily diet should provide no more than $30 \%$ of the energy requirement, incl. in equal quantities separate fractions of fatty acids, namely SFA:MUFA:PUFA=1:1:1 [4, p. 6].

Such a composition of "ideal" fat is basic for the development of norms of physiological needs of the population in basic nutrients and energy. Depending on the number of $\mathrm{C}$ atoms from the end of the fatty acid chain to the nearest double bond, it can be attributed to one of the groups: $\omega-3$, $\omega-6, \omega-7, \omega-9$ etc. 
FA can perform various functions, including bioenergetics. In this case, some fatty acids are part of intracellular phosphoglycerols, sphingomyelins, cerebrosides, and other biologically active lipids, which are the most important structural elements of cells (membranes, liposomes).

Such FA that perform unique plastic functions include arachidonic acid

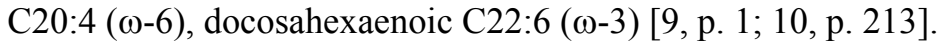

The high proportion of $\omega-3$ acids in the product contributes to the prevention of a number of diseases, including cancer. In conditions of specific unsaturated FA deficiency, the tails of saturated FA such as stearic, for example, are embedded in the structure of plastic lipids.

The authors [11, p. 678] proved that such replacement causes the destruction of cells of the smooth muscle of the heart due to the decrease in plasticity and permeability of membranes. Damage to the heart muscle is prevented by the addition of unsaturated FA to the diet [12, p. 63].

Experiments on many mammalian species have shown that deficiency or absence in the PUFA diet leads to profound disturbances in vital processes, the main ones being growth retardation in young and inability to reproduce in sexually mature organisms [13, p. 284].

Researchers have shown that essential PUFA are synthesized from simpler linoleic and linolenic acids. Essential PUFA such as eicosapentaenoic and docosahexaenoic FA, which are representatives of the $\omega-3$ FA families, are synthesized by lengthening the carbon chain and forming double bonds in the linoleic acid molecule. Arachidonic acid and other FA belonging to the $\omega-6$ PUFA family are formed from linoleic acid through the extension of the carbon chain and the formation of double bonds [14, p. 154].

Biological functions of food $\omega-3$ FA in the body [15, p. 194]: provide energy and carbon atoms; eicosapentaenoic and docosahexaenoic (DHE) fatty acids are a precursor to $\omega-3$ eicosanoids; the data increase indicates the specific role of DHE in membrane function, especially in the retina and neuronal tissues. Deficiency of $\omega-3$ PUFA results in loss of DHE in brain phospholipids and retina with compensatory replacement 22:5 $\omega-6$. This slight change in the phospholipid structure of the membrane is sufficient to cause memory loss, mental impairment and visual acuity.

Linoleic acid is a structural component in ceramides of the water barrier in the skin; arachidonic acid is a precursor to eicosanoids. $\omega-6$ FA may also play the role of a second messenger in the process of signaling through cell mem- 
branes. Linoleic FA deficiency may occur as a secondary condition in other disorders such as lack of protein and impaired fat absorption, as a result of complete parenteral nutrition with insufficient intake of linoleic acid [16, p. 345].

According to the results of studies of the Ukraine population diet, the fact of excessive consumption of SFA at the expense of consumption of dairy products and $\omega-6$ FA at the expense of sunflower oil consumption has been established $[17$, p. 5]. However, the ratio of $\omega-6$ to $\omega-3$ FA in the human diet is an important indicator. It is scientifically proved that essential FA must account for 4-6\% of the energy value of the daily diet of an adult, and the ratio $\omega-6 / \omega-3$ PUFA should be $10: 1$, and in cases where there is a violation of lipid metabolism - 5:1 and even $3: 1$ [18, p. 9, 19, p. 53]. For the elderly, the content of linoleic acid should be about $40 \%$, and linolenic acid $-4 \%$, the ratio of PUFA to SFA - 2:1 [6, p. 8; 20, p. 180].

The analysis of the results of the actual nutrition of the population of Ukraine shows that these acids actually enter the human body in the ratio of 10:1 to $30: 1$ [21, p. 49].

That is, some of the useful for preventing age-related diseases of the FA family $\omega$-3 against other unsaturated FA should be as large as possible.

Hence, the correction of low intake of $\omega-3$ PUFA and the reduction of total fat intake in the human diet to physiologically based norms is an urgent task for nutritionists and food producers.

This can be addressed through the development and implementation of new combined meat products with balanced FAC.

Therefore, the purpose of our work was to study and analyze the biological efficiency of fats of meatcontaining combined foods with balanced FAC.

\section{Materials and methods}

To achieve this goal as a model for the study of the fat biological effectiveness of meatcontaining poultry meat products, which, in addition to the actual use of poultry meat and poultry meat mechanically deboned [22, p. 145] was combined meat of waterfowl and freshwater fish for cooked products on the example of sausages with Muscovy duck meat, sausage cooked with Muscovy duck meat and silver crucian meat, meat bread with Muscovy duck meat and silver carp.

Meatcontaining sausages technology used Muscovy duck meat, soy isolate, pork skin emulsion, milk powder and a functional supplement Fibra 110 (Germany) were also introduced into the recipe. 
The recipe for the control sample of sausages included duck, pork fat, first-grade beef, starch, salt and spices, sodium nitrite [23, p. 97-98]. Formulations of sausages are presented in table 1 .

Table 1

Developed recipes of sausages with Muscovy duck meat

\begin{tabular}{|l|c|c|}
\hline \multicolumn{1}{|c|}{ Ingredients } & Control sample & Test sample \\
\hline Duck meat & 40 & - \\
\hline Muscovy duck meat & - & 40 \\
\hline Pork fat & 10 & 10 \\
\hline Soy isolate & - & 10 \\
\hline First-grade beef & 47 & 10 \\
\hline Milk powder & - & 3 \\
\hline Fibra 110 & - & 2 \\
\hline Pork skin emulsion & - & 25 \\
\hline Starch & 3 & - \\
\hline Total & 100 & 100 \\
\hline Salt & 2,5 & 2,5 \\
\hline NaNO2 & 0,005 & 0,005 \\
\hline Sugar & 0,1 & 0,1 \\
\hline Spices & 0,35 & 0,35 \\
\hline
\end{tabular}

In addition, a formulation of meatcontaining sausage cooked from the waterfowl and Carassius gibelio meat was developed, which included the ingredients in the following ratio: Muscovy duck meat 35\%, minced fish (Carassius gibelio) $45 \%$, pork fat $10 \%$, milk powder whey $5 \%$, wheat flour $1 \%$, chicken eggs $4 \%$ and spices. The boiled sausage "Otdelnaya", which included $60 \%$ beef, $23 \%$ pork, $15 \%$ pork fat was taken as an anague [24, p. 18].

Meat bread "Chainyi" was chosen as an analogues for the production (DSTU 4436:2005) [25, p. 20].

Muscovy duck meat was used to make prototypes. Duck minced meat was prepared according to a standard technological scheme. Duck meat is deboned, skimmed and ground into a chopper with a diameter of 2-3 $\mathrm{mm}$.

Also in the formulations of experimental samples was introduced white silver carp. Formulation options are shown in table 2. 
Recipes of meatcontaining breads

\begin{tabular}{|l|c|c|}
\hline \multicolumn{1}{|c|}{ Ingredients } & Control sample & Test sample \\
\hline Second-grade beef & 70 & - \\
\hline Pork & 20 & - \\
\hline Muscovy duck meat & - & 30 \\
\hline Minced meat of white carp & - & 45 \\
\hline Dry demineralized whey & - & 5 \\
\hline Pork fat & 8 & 10 \\
\hline Wheat flour & 2 & 2 \\
\hline Aprored & - & 3 \\
\hline Fibra 110 & - & 2 \\
\hline Melange & - & 3 \\
\hline Solt & 1,5 & 1,5 \\
\hline Sodium nitrite & 0,0075 & 0,0075 \\
\hline Spices & 0,35 & 0,35 \\
\hline Sugar & 0,1 & 0,1 \\
\hline
\end{tabular}

In finished products, the nutritional value was determined by the calculation method [26, p. 354], in the experimental samples the content of the FA was determined and the ratio of the FA was calculated according to the recommended daily requirement.

Determination of fatty acids sausages was carried out by gas-liquid chromatography using the automated gas chromatograph Kupol-55 [27, p. 3-10] (Figure 1). To determine the FA a sample was prepared by lipid extraction. A mixture of chloroform-methanol (1:2) and water in a ratio of 30:3 $\mathrm{ml}$ was added to $6 \mathrm{~g}$ of sample and homogenized the mixture for $2 \mathrm{~min}$. at room temperature.

Homogenized sample was centrifuged, the residue was re-extracted $38 \mathrm{ml}$. mixtures of chloroform:methanol:water $(1: 2: 0.8)$ in a homogenizer for $2 \mathrm{~min}$.

The extract was separated by centrifugation; the combined supernatants are diluted in $20 \mathrm{ml}$ of chloroform and $20 \mathrm{ml}$ water. The water-methanol and chloroform phases are separated by centrifugation. The lower layer of chloroform is concentrated on a rotary evaporator at a temperature of 30-350C. The residue is dissolved in $10 \mathrm{ml}$ chloroform. 
For fattening, $10 \mathrm{~g}$ fat, $3.9 \mathrm{~g} \mathrm{KOH}$ and $50 \mathrm{ml} 96 \%$ ethyl alcohol were combined. During 2-3 hours, the mixture was heated with a reflux condenser in an inert gas atmosphere, occasionally shaking the flask. After this time, the mixture was cooled, diluted with distilled water $(1: 1)$, neutralized with $10 \% \mathrm{H} 2 \mathrm{SO} 4$ to $\mathrm{pH}=7$, and acidified to $\mathrm{pH}=2$. The mixture was extracted in $200 \mathrm{ml}$ divalent funnel by sulfuric ether; the procedure was repeated three times in the ratio 1:0.5. The combined ether extracts were washed twice with distilled water, and then dried with anhydrous sodium sulfate.

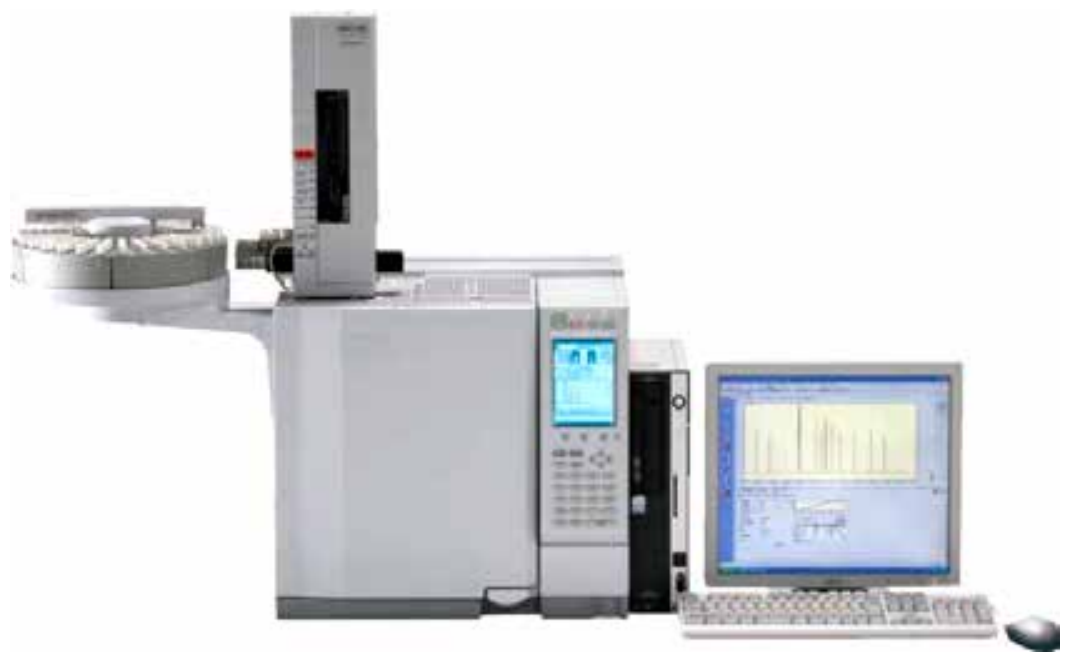

Figure 1. Chromatograph Kupol-55 (Russia)

The extract was concentrated on a rotary evaporator at a temperature not above 400C. After heating in a water bath for $50 \mathrm{~min}$., the extract was diluted with water in a ratio of $1: 1$. Then hexane extracts were obtained.

The hexane was evaporated on a rotary evaporator to give chromatographically pure methyl esters of fatty acids, which were dissolved in hexane and chromatographed on a Kupol-55 (Russia) chromatograph on a column of SP 2560 (USA) in length $100 \mathrm{~m}$. The absolute error of measurements was determined by Student criterion, the reliable interval $\mathrm{P}=0,95$, the number of repeats in calculations $-3-4$, the number of parallel tests of studied samples -3 . 


\section{Results and discussion}

According to the calculations of the nutritional value of meatcontaining sausages with Muscovy duck meat fat content in the recipe-analogue was $23.76 \mathrm{~g} / 100 \mathrm{~g}$ of the product, while in the developed sample of the recipe, this index decreased by an average of $10,65-15,45 \%$.

The results of the chromatographic study of the content of FA meatcontaining sausages with Muscovy duck meat are presented in Figure 2 and Table 3.

FA of meatcontaining sausages with Muscovy duck meat is represented mainly by palmitic $(24.15 \%)$, stearic $(10.92 \%)$ and myristic $(1.47 \%)$ acids, among unsaturated ones - oleic (39.78\%), linoleic (14.40\%), $\alpha$-linolenic $(1.65 \%)$ acids.

Table 3

The results of the study of the biological effectiveness of fat meat-containing sausages with Muscovy duck meat

\begin{tabular}{|l|c|}
\hline \multicolumn{1}{|c|}{ Type of fatty acid } & Concentration, $\mathbf{g} / \mathbf{1 0 0} \mathbf{g}$ fat \\
\hline Myristic acid (C14:0) & 1,47 \\
\hline Palmitic (C16:0) & 24,15 \\
\hline Margaric acid (C17:0) & 0,48 \\
\hline Stearic acid (C18:0) & 10,92 \\
\hline Arachic acid (C20:0) & 0,61 \\
\hline Total SFA & $\mathbf{3 7 , 6 3}$ \\
\hline \multicolumn{2}{|c|}{ Monounsaturated fatty acids (MUFA) } \\
\hline Palmitoleic acid (C16:1) & 3,05 \\
\hline Oleic acid (C18:1) trans $\omega-9$ & 0,24 \\
\hline Oleinic acid (C18:1) cys $\omega-9$ & 39,78 \\
\hline Total MUFA & $\mathbf{4 3 , 0 7}$ \\
\hline \multicolumn{2}{|c|}{ Polyunsaturated fatty acids (PUFA) } \\
\hline Linoleic acid (C18:2) trans $\omega-6$ & 0,12 \\
\hline Linoleic acid (C18:2) cys $\omega-6$ & 14,40 \\
\hline$\alpha-$ Linolenic acid $(\mathrm{C} 18: 3) \omega-3$ & 1,65 \\
\hline Eicosotrienoic acid $(\mathrm{C} 20: 3) \omega-3$ & 0,40 \\
\hline Total PUFA & $\mathbf{1 6 , 5 7}$ \\
\hline
\end{tabular}




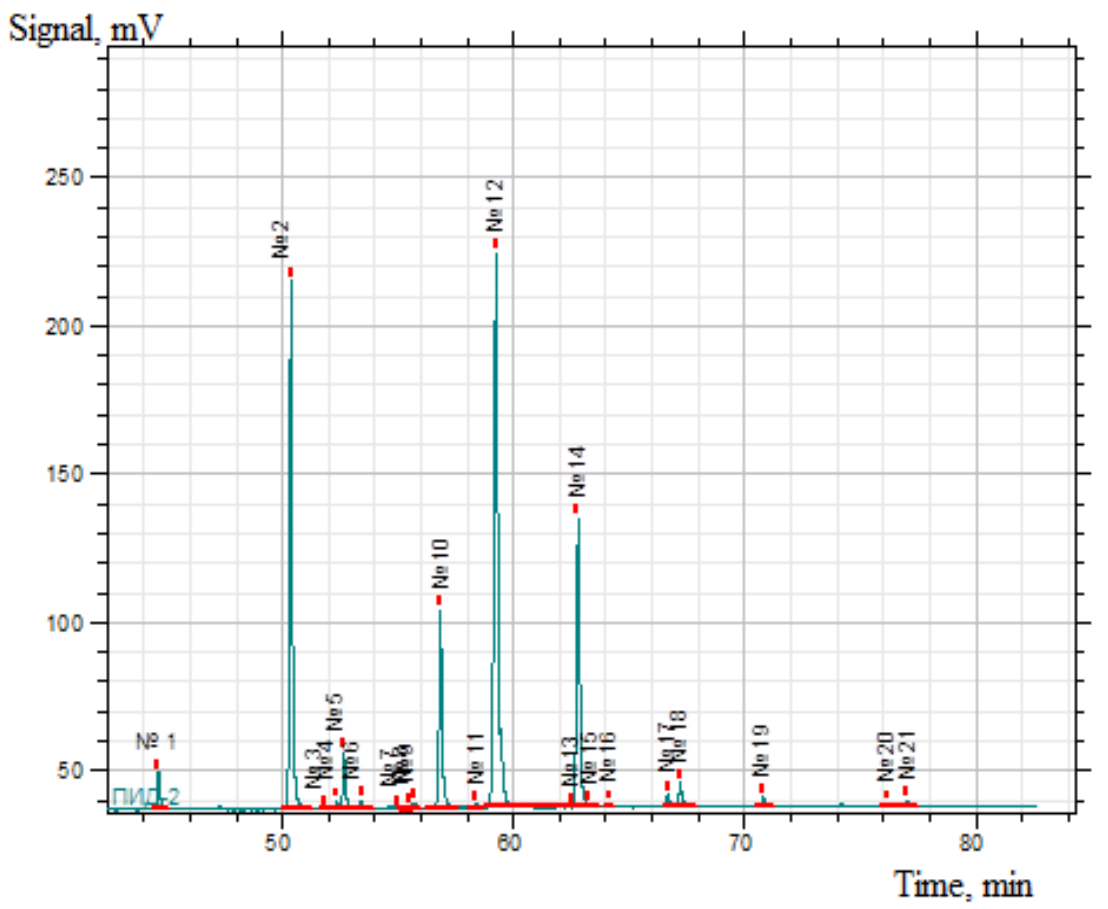

Figure 2. Fatty acids chromatogram of meatcontaining sausages with Muscovy duck meat

FA analysis of meatcontaining sausages confirms that this product contains a concentration of oleic acid cys-isomer at the level of $39.78 \mathrm{~g} / 100 \mathrm{~g}$ of fat.

The total amount of PUFA was $16.57 \mathrm{~g} / 100 \mathrm{~g}$ fat, including a high content of linoleic acid cys and trans configurations (14.52 g/100 g), which belongs to the family $\omega-6$.

The FA is balanced in a food product in which the ratio between individual types of FA is: PUFA:MUFA:SFA - 1:6:3. According to nutritionists, the recommended ratio of FA content of the family $\omega-6$ (linoleic, $\gamma$-linolenic and arachidonic acids) to the family $\omega-3$ (alinolenic, eicosapentaenic and docosahexaenic acids) in the diet of healthy person should be: (8-10):1, and in medical nutrition - from 3:1 to 5:1 [19, p. 53]. 
The results of nutritional value studies of cooked sausage with duck meat and silver carp showed that the fat content in the control sample was $27.79 \mathrm{~g} / 100 \mathrm{~g}$ of the product, which is $17.6 \%$ higher than in the experimental sample.

The amount of energy per $100 \mathrm{~g}$ of sausage was $257 \mathrm{kcal}$, which is related to the ratio of fish and meat raw materials. The energy value of the control sample was $318.14 \mathrm{kcal}$ per $100 \mathrm{~g}$ of product, which is $24 \%$ higher than in the experimental boiled sausage.

The results of the chromatographic study of the FA content of meatcontaining cooked sausage with Muscovy duck meat and Carassius gibelio are presented in Figure 3 and Table 4.

Table 4

\section{Results of the FA study of meatcontaining cooked sausage} with duck meat and Carassius gibelio

\begin{tabular}{|l|c|}
\hline \multicolumn{1}{|c|}{ Type of fatty acid } & Concentration, g/100 g fat \\
\hline \multicolumn{2}{|c|}{ Saturated fatty acids (SFA) } \\
\hline Myristic acid (C14:0) & 1,73 \\
\hline Palmitic (C16:0) & 26,79 \\
\hline Margaric acid (C17:0) & 4,43 \\
\hline Stearic acid (C18:0) & 7,87 \\
\hline Arachic acid (C20:0) & 0,61 \\
\hline Total SFA & $\mathbf{4 1 , 4 3}$ \\
\hline \multicolumn{2}{|c|}{ Monounsaturated fatty acids (MUFA) } \\
\hline Palmitoleic acid (C16:1) & 0,49 \\
\hline Oleic acid (C18:1) trans $\omega-9$ & 0,47 \\
\hline Oleinic acid $(\mathrm{C} 18: 1)$ cys $\omega-9$ & 45,05 \\
\hline Total MUFA & $\mathbf{4 6 , 0 1}$ \\
\hline \multicolumn{2}{|c|}{ Polyunsaturated fatty acids (PUFA) } \\
\hline Linoleic acid (C18:2) trans $\omega-6$ & 0,39 \\
\hline Linoleic acid (C18:2) cys $\omega-6$ & 11,14 \\
\hline$\alpha-$ Linolenic acid $(\mathrm{C} 18: 3) \omega-3$ & 1,14 \\
\hline Total PUFA & 12,67 \\
\hline
\end{tabular}

Analyzing the FA composition of meatcontaining cooked sausage with Muscovy duck meat, it confirms that this product contains a concentration of cys-isomer of oleic acid in sausage at the level of $45.05 \mathrm{~g} / 100 \mathrm{~g}$ of fat. 


\section{Signal, $\mathrm{mV}$}

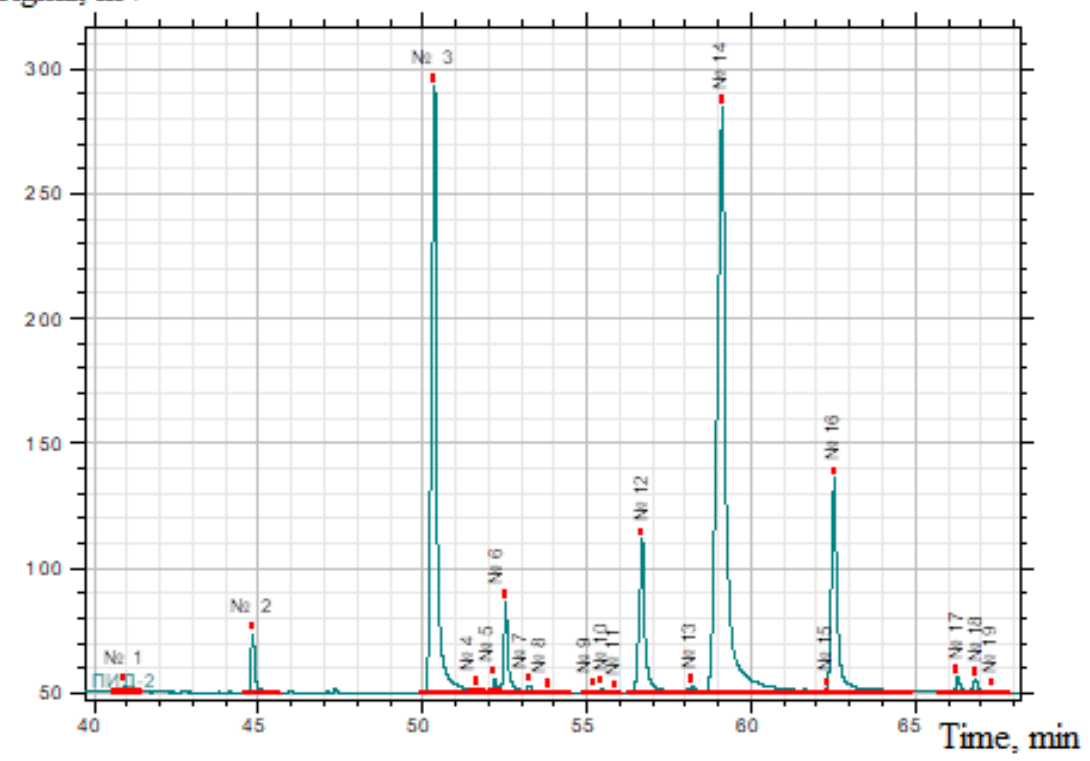

Figure 3. Chromatogram of fatty acid analysis of meatcontaining cooked sausage with duck meat and Carassius gibelio

The total amount of PUFA was $12.67 \mathrm{~g} / 100 \mathrm{~g}$ fat, including a high content of linoleic acid $(11.14 \mathrm{~g} / 100 \mathrm{~g})$, which belongs to the family $\omega-6$.

The level of SFA is $41.43 \%$ in the fat of the product or $g / 100 \mathrm{~g}$, among which the dominant is palmitic $(26.79 \mathrm{~g} / 100 \mathrm{~g}$ fat $)$ and stearic (7.87 g/100 g fat).

In the metabolism of humans involved, first of all, such PUFA: palmitooleic, oleic, linoleic, linolenic. All of these fatty acids were found in meatcontaining cooked sausage with Muscovy duck meat and Carassius gibelio.

A sufficient content of essential linoleic FA has been noted in boiled sausage $(11.14 \mathrm{~g} / 100 \mathrm{~g})$, which is a precursor of families of long-chain PUFA performing regulatory and plastic functions $[28$, p. $523 ; 29$, p. 8].

The results of nutritional value studies of meatcontaining bread showed that the fat content of the developed sample decreased compared to the control. In general, the reduction in mass fraction of fat was $24 \%$. 
In contrast to the control sample, the test sample contained carbohydrates: lactose, in the amount of $5.14 \%$ due to the use of dry demineralized whey; dietary fiber $-2.07 \%$ due to flour and soluble fiber Fibra 110 (Germany).

The energy value of the prototype decreased and amounted to almost $264 \mathrm{kcal}$ in $100 \mathrm{~g}$, which is $11.4 \%$ less than the recipe-analogue.

Protein in experimental sample increased from $7.8 \%$ to $17.47 \mathrm{~g} / 100 \mathrm{~g}$.

The results of the chromatographic study of the content of FA of meatcontaining bread with Muscovy duck meat and silver carp are presented in Figure 4 and Table 5.

Table 5

\section{Results of a FA study of meatcontaining bread with Muscovy duck meat and silver carp}

\begin{tabular}{|l|c|}
\hline \multicolumn{1}{|c|}{ Type of fatty acid } & Concentration, $\mathbf{g} / \mathbf{1 0 0}$ g fat \\
\hline \multicolumn{2}{|c|}{ Saturated fatty acids (SFA) } \\
\hline Myristic acid (C14:0) & 1,73 \\
\hline Palmitic (C16:0) & 24,94 \\
\hline Margaric acid (C17:0) & 4,53 \\
\hline Stearic acid (C18:0) & 9,58 \\
\hline Arachic acid (C20:0) & 1,68 \\
\hline Total SFA & $\mathbf{4 2 , 4 6}$ \\
\hline \multicolumn{2}{|c|}{ Monounsaturated fatty acids (MUFA) } \\
\hline Palmitoleic acid (C16:1) & 0,77 \\
\hline Oleic acid (C18:1) trans $\omega-9$ & 0,71 \\
\hline Oleinic acid (C18:1) cys $\omega-9$ & 45,48 \\
\hline Total MUFA & $\mathbf{4 6 , 9 6}$ \\
\hline \multicolumn{2}{|c|}{ Polyunsaturated fatty acids (PUFA) } \\
\hline Linoleic acid (C18:2) trans $\omega-6$ & 0,17 \\
\hline Linoleic acid $(\mathrm{C} 18: 2)$ cys $\omega-6$ & 8,61 \\
\hline$\alpha-$ Linolenic acid $(\mathrm{C} 18: 3) \omega-3$ & 1,07 \\
\hline Total PUFA & $\mathbf{9 , 8 5}$ \\
\hline
\end{tabular}

According to the table, the total level of SFA is lower than the total level of unsaturated FA. The total amount of SFA was $42.46 \mathrm{~g} / 100 \mathrm{~g}$ fat, whereas unsaturated was $56.81 \%$.

Monoene FA were found in the amount of $46.96 \%$ and polyene in the number of $9.85 \%$. 


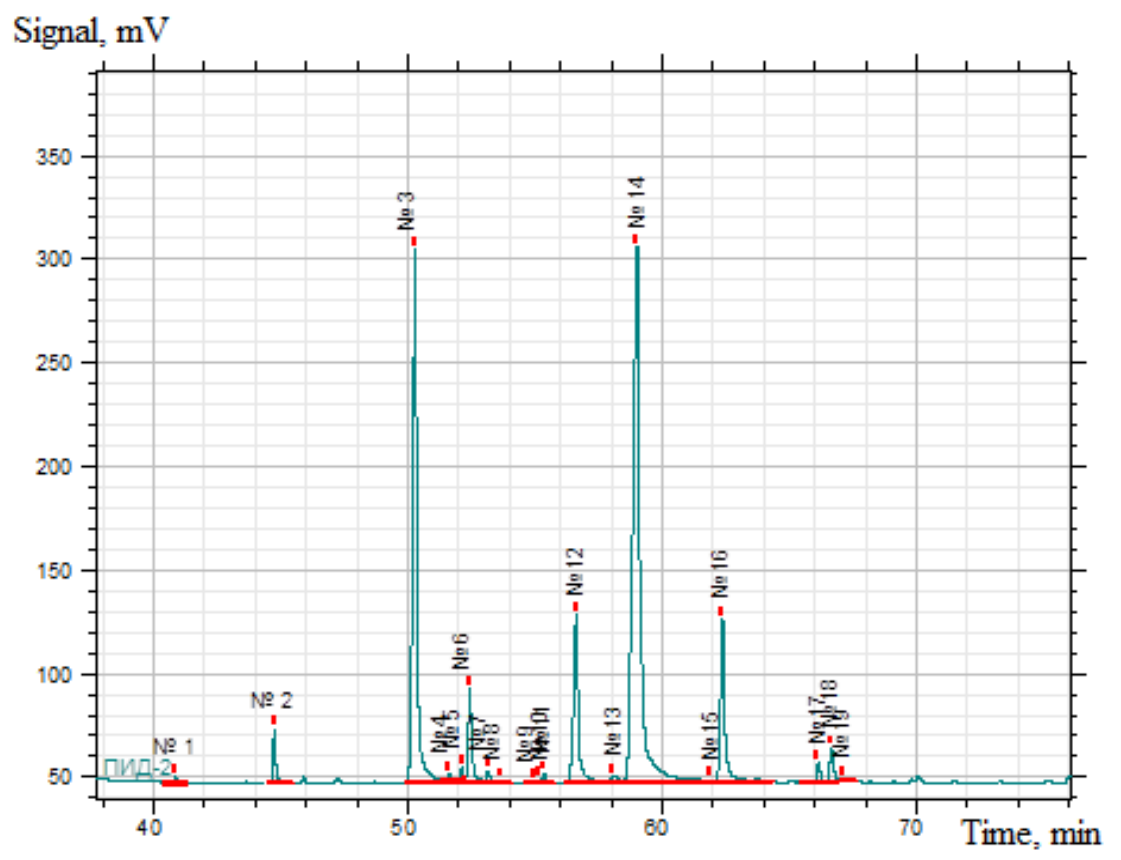

Figure 4. Chromatogram of fatty acid analysis of meatcontaining bread with Muscovy duck meat and silver carp

It should be noted that the trans isomers of the FA are discovered in minimal quantities and only for two FA: oleic $-0.71 \mathrm{~g} / 100$ fat and linoleic $-0.17 \%$.

The presence of trans isomers of unsaturated FA in food has long been associated with a negative impact on the body. It is proved that trans - FA increase the probability of cardiovascular diseases [30, p. 7].

Among the omega- 6 acids, linoleic acid prevailed in the sample, the average content of which in the cys form was $8.61 \%$; also found $\alpha$-linolenic acid in the amount of $1.07 \mathrm{~g} / 100 \mathrm{~g}$ of fat.

The biological efficiency of food lipids is characterized by the balance and level of FA compliance with the body's physiological needs in accordance with current nutritionists' recommendations.

A number of scientific organizations and governments in some countries have recognized the need to increase the consumption of FA family $\omega-3$ in 
the diet. Summarizing the scientific data and recommendations of experts from different countries of the world, we can conclude that common to all the recommendations is the emphasis on the need for daily consumption of $\omega-3 \mathrm{FA}$ in the amount of 1.0-2.0 g per day. For the greatest biological effect, the proposed ratio of $\omega-3 / \omega-6$ should be from $1: 4$ to $1: 10$ [31, p. 23 ; 32 , p. $35 ; 33$, p. $300 ; 34$, p. $384 ; 35$, p. 16 ; 36, p. 2294].

Indexes of biological efficiency of cooked sausages lipids in the compared with the standard are shown in table 6.

Table 6

Indexes of biological efficiency

of meatcontaining cooked sausages lipids

\begin{tabular}{|c|c|c|c|c|}
\hline \multirow[b]{2}{*}{ Indexes of biological efficiency } & \multicolumn{4}{|c|}{ Samples } \\
\hline & 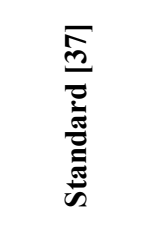 & 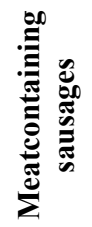 & 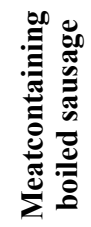 & 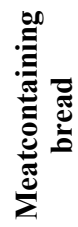 \\
\hline $\begin{array}{l}\omega-3 \text { fatty acid content, } g / 100 \mathrm{~g} \\
\text { of product }\end{array}$ & {$[37]$} & 0,50 & 0,26 & 0,21 \\
\hline $\begin{array}{l}\text { The level of satisfaction of the } \\
\text { recommended daily } \omega-3 \text { PUFA } \\
\text { requirement, } \%\end{array}$ & $\begin{array}{c}1,5 \Gamma \\
(100 \%)\end{array}$ & 32,47 & 17,48 & 14,27 \\
\hline $\begin{array}{l}\text { Linoleic fatty acid content, } \\
\mathrm{g} / 100 \mathrm{~g} \text { of product }\end{array}$ & $11,3-16,3$ г & 3,42 & 2,56 & 1,72 \\
\hline $\begin{array}{l}\text { The satisfaction level of the } \\
\text { recommended daily requirement } \\
\text { for linoleic acid,\% }\end{array}$ & $\begin{array}{c}13,8 \text { г } \\
(100 \%)\end{array}$ & 30,27 & 22,67 & 15,25 \\
\hline $\begin{array}{l}\alpha \text {-linolenic fatty acid content, } \\
\mathrm{g} / 100 \mathrm{~g} \text { of product }\end{array}$ & $1,1-1,6$ г & 0,39 & 0,26 & 0,21 \\
\hline $\begin{array}{l}\text { The satisfaction level of the } \\
\text { recommended daily requirement } \\
\text { for } \alpha \text {-linolenic acid, } \%\end{array}$ & $\begin{array}{c}1,4 \Gamma \\
(100 \%)\end{array}$ & 28,00 & 18,73 & 15,29 \\
\hline $\begin{array}{l}\omega-6 \text { fatty acid content, } g / 100 \mathrm{~g} \\
\text { of product }\end{array}$ & 5,6 & 3,42 & 2,56 & 1,72 \\
\hline The ratio of fatty acids $\omega-3 / \omega-6$ & $1: 5-1: 10$ & $1: 7$ & $1: 9,8$ & $1: 8$ \\
\hline
\end{tabular}


It has been experimentally found that lipids of meatcontaining cooked products are characterized by high values of biological efficiency. It is experimentally determined that the high content of $\omega-3$ PUFA in the developed cooked products ranges from 0.21 to $0.50 \mathrm{~g}$ per $100 \mathrm{~g}$, which allows to provide from 14.27 to $32.47 \%$ of the recommended daily requirement.

This allows considering meatcontaining cooked products with duck meat and fish raw materials as a source of $\omega-3$ PUFA for inclusion in the daily diet of an adult.

Considering the available scientific data on a wide range of clinical and pharmacological effects of $\omega-3$ PUFA (hypotriglyceridemic, antiatherogenic, antiarrhythmic, anti-inflammatory and hypotensive), meatcontaining cooked products with Muscovy duck meat and freshwater aquaculture can be recommended for use in production food for healthy nutrition.

It is shown that the ratio of the concentration of linoleic to linolenic FA is much less than the recommended one, which is the reason for the predominance of linolenic acid, the deficiency of which is characteristic of the diet of the inhabitants of Ukraine [3, p. 7].

The satisfaction level of the recommended daily requirement for linoleic acid at the expense of meatcontaining products of the cooked group is from $15,25-30,27 \%$, and for linolenic - 15,29-28\%.

That is, consuming 100 grams of meatcontaining cooked sausages with duck meat can satisfy a person's need for $\omega-3$ fatty acids by $28 \%$ and for $\omega-6$ by $30.27 \%$.

FA ratio $\omega-3 / \omega-6$ ranks within 1:7 - 1:9,8, which corresponds to the recommended physiological standards of nutrition for a healthy person.

\section{Conclusions}

1. Studies have confirmed that FAC of cooked meat products are characterized by a high content of unsaturated, including essential, FA in their composition - linoleic, oleic, linolenic

2. The high content of monounsaturated C18:1 $\omega-9$ (oleic) FA was experimentally established in all products developed - 43.07-45.48 g/100 g fat. It is proved that the significant content of $\omega$-3 PUFA, deficiency of which is characteristic for the nutrition of the Ukraine's population, in the developed meatcontaining products of the cooked group (0.21-0.39 g/100 g of product) can satisfy the recommended daily requirement for essential FA for $28 \%$. 
3. The determination of the content of FA trans-isomeric form showed that their concentration is negligible and is at the level of $0.12-0.71 \mathrm{~g} / 100 \mathrm{~g}$ of fat at the maximum allowable concentration of trans-isomers in the combined fats is not more than $8 \%$.

4. It is experimentally determined that the ratio between individual families FA $\omega-3 / \omega-6$ in the developed products is from $1: 7$ to $1: 9,8$ at the recommended physiological norms of the ideal fat composition in the diet 1:5-1:10. That is cooked meatcontaining products made with the combination of Muscovy meat and freshwater aquaculture meat can be recommended for healthy nutrition.

5. The above results suggest that the use of the proposed recipe solutions of meat-containing combined products cooked group increases their nutritional value in terms of biological efficiency.

6. It has been found that lipids of meatcontaining cooked products meet the optimum values for the most of the calculated biological efficacy indicators. Taking into account the systematized data on a wide range of clinical and pharmacological effects of $₫-3$ and $₫-6$ PUFA, it is possible to consider meatcontaining combined products of cooked group based on duck meat and freshwater aquaculture as a source of essential FA in the human diet and use them for recovery of healthy lipid balance disorders in the diets of the modern Ukraine's population.

\section{References:}

1. Pasichnyi V.M. (2002). Ranhove otsiniuvannia kombinovanykh miasoproduktiv. Naukovi pratsi NUKhT, 11, 77-80.

2. Peshuk L.V., Radzyevskaya Y.G., Kyshhenko V.A., Levchuk Y.V. (2011). Sravnytelnyj analyz zhyrnokyslotnogo sostava tradycyonnyh y ekzotycheskyh vydov syrya. Zhurnal xromatografichnogo tovarystva, t. XI, 3,4, 42-48.

3. Smolyar V.I. (2012). Stan faktychnogo harchuvannya naselennya nezalezhnoyi Ukrayiny. Problemy xarchuvannya, 1-2, 5-9.

4. Levyczkyj A.P. (2002). Idealnaya formula zhyrovogo pytanya. Odessa: NPA "Odesskaya byotehnologya", $61 \mathrm{~s}$.

5. Smolyar V.I. (2006). Koncepciya idealnogo zhyrovogo harchuvannya. Problemy harchuvannya, 4, 14-24.

6. Subbotina M.A. (2009). Fiziologicheskie aspektyi ispolzovaniya zhirov v pitanii. Tehnika i tehnologiya pischevyih proizvodstv. V. 4, 8-13.

7. Hansen A. (1987). Lipid in modern nutrition. N.-Y.; Raven Press, 248 p.

8. Jones P., Rideout T. (2012). Modern Nutritionin Health and Disease (Lipids, Sterols, and Their Metabolites) in book Modern Nutritionin Health and Disease, Wolters Kluwer Health, 65-87. 
9. Pubchem.5,8,11,14-Eicosatetraenoic acid C20H32O2 -PubChem.

10. Horrocks L.A., Yeo Y.K. (1999). Health benefits of docosahexaenoic acid (DHA). Pharmacological Research. T. 40(3), 211-225.

11. Riediger N.D., Othman R.A., Suh M. et al. (2009). A systematic review of the rolesof the n-3 fatty acid in healt handdisease. J. Am. Diet Assoc. 109(4): 668-679. doi: http://dx.doi.org/10.1016/j.jada.2008.12.022

12. Fedorova, D. (2017). Doslidzhennya zhyrnokyslotnogo skladu lipidiv suhyh ryboroslynnyh napivfabrykativ. Food Science and Technology, 11(3), 61-70. https://doi.org/10.15673/fst.v11i3.608

13. Benatti P., Peluso G., Nicolai R., Calvani M. (2004). Polyunsaturated Fatty Acids: Biochemical, Nutritional and Epigenetic Properties. Journal of the American College of Nutrition, 23(4), 281-302.

14. Sprecher H, Chen Q, Yin FQ.( 1999). Regulation of the biosynthesis of 22:5n-6 and 22:6n-3: a complex intracellular process. Lipids, 34, 153-156.

15. Lauritzen L., Hansen H.S., Jorgensen M.H., Michaelsen K.F. (2001). Theessentiality of long-chain n-3 fatty acids in relation to development and function of the brain and retina. Prog Lipid Res, 40, 194.

16. James M.J., Gibson R.A., Cleland L.G. (2000). Dietary polyunsaturatedfatty acids and inflammatory mediator production. Am J Clin Nutr, 71, 343-348.

17. Smolyar V.I. (2011). Zakony racionalnogo harchuvannya v suchasnij nutriciologiyi. Problemy harchuvannya, 1(2), 5-13.

18. Yvankyn A.N. (2007). Zhyry v sostave sovremennyx myasnyx produktov. Myasnaya industriya, 6, 8-13.

19. Hughes CL, Dhiman TR: (2002). Dietary compound sinrelation todietarydiversity and humanhealth. JMedFood, 5, 51-68.

20. Etherton R., Taylor D.L., Poth S. Yu, Huth P., Moriarty K., Fishell V., Hargrove R., Zhao G., Etherton T. (2000). Polyunsaturated fatty acids in th food chain in the United States.// Am. J. Clin. Nutr. 71. P. 179-188. doi: 10.1093/ajen/71.1.179S

21. Matasar Y. i dr. (2002). Socyalnodemografycheskaya xarakterystyka i faktycheskoe pytanye zhenshhyn, prozhyvayushhyx v Ukraine. Liky Ukrayiny, 11, 49-54.

22. Bozhko, N., Pasichniy, V., Bordunova, V. (2016). Meat-containing cooked sausage containing the meat of a duck. Scientific Messenger of LNU of Veterinary Medicine and Biotechnologies. Series: Food Technologies, 18(2), 143-146. URL: https://doi.org/10.15421/nvlvet6829

23. Bozhko N.V., Tishhenko V.I., Pasichnyi V.M. ta in. (2017). Rozrobka receptury sardelok iz myasa muskusnoyi kachky. Progresyvni tehnika ta tehnologiyi harchovyh vyrobnycztv restorannogo gospodarstva i torgivli. Vyp. 2(26), 94-104.

24. Bozhko, N.V., Tishhenko, V.I., Pasichnyj, V.M., Konyk, M.V. (2019). Rozrobka receptury varenyh kovbas iz myasom vodoplavnoyi ptyci ta malocinnoyi stavkovoyi ryby. Naukovyj visnyk PUET: Technical Sciences, 1(85), 17-24.

25. Bozhko, N., Tischenko, V., Pasichnyi, V., Yuschko, M., Zhukova, Y., Popova, E. (2018). Study of functional and technological indices of meat-containing loafwith Muscovy duck meat and whitecarp. Scientific Messenger of LNU of Veterinary Medicine and Biotechnologies. Series: Food Technologies, 20(85), 19-23. URL: https://doi.org/10.15421/nvlvet8504 
26. Antypova L.V., Glotova Y.A., Rogov Y.A. (2001). Metody issledovanya myasa y myasnyh produktov. Moskva, $576 \mathrm{~s}$.

27. DSTU ISO 15885/IDF 184:2008 (2011). Zhyr molochnyj. Vyznachennya zhyrnokyslotnogo skladu metodom gazoridynnoyi hromatografiyi. Metody ekstraguvannya lipidiv ta liporozchynnyh spoluk». Kyiv, $12 \mathrm{~s}$.

28. Simopoulos, A. (1989). Summary of the NATO advanced research workshop on dietary omega-3 and omega-6 fatty acid: biological effects and nutritional essentiality. The Journal of Nutrition. 119, 521-528.

29. Fats and oils in human nutrition: (2010). Report of an expert consultation: FAO food and nutrition paper. Rome: FAO. 169 p.

30. Bessonov V.V., Zajceva L.V. (2016). Transizomery zhyrnyh kyslot: rysky dlya zdorovya i puty snyzhenyya potreblenyya. Voprosy pytanyya, 85(3), 6-17. doi: 10.24411/0042-8833-2016-00030

31. Fats and oils in human nutrition: (1994). Report of a Joint FAO/WHO Expert Consultation: Fat and Nutrition paper 57/ FAO/WHO. Rome: FAO. 147 p.

32. Dietary Reference Values for Food Energy and Nutrients for the United Kingdom: (1991). Report of the Panel on Dietary Reference Values of the Committee on Medical Aspects of Food Policy/ Report on Health and Social Subjects. London: 41.210 p.

33. Simopoulos, A.P. (1999). Workshop on the Essentiality of and Recommended Dietary Intakes for Omega-6 and Omega-3 Fatty Acids. Asia Pacific Journal of Clinical Nutrition, 8, 300-301. doi: 10.1046/j.1440-6047.1999.00123.x

34. Ambroise Martin, coordonnateurgénéral; coordonnateurs, Véronique AzaïsBraesco, Jean-Louis Bresson, Charles Couet. [et al.].(2016). Apportsnutritionnels conseillés pour la population française CNERNA-CNRS AFSSA, Agencefrançaise de sécuritésanitairedes aliments. Paris: Tec\&Doc, $591 \mathrm{p}$.

35. Letter legarding dietary supplement health claim for omega-3 fatty acids and coronary heart disease (2000). U. S. Food and Drug Administration Center forFood Safety and Applied Nutrition. Office of Nutritional Products, Labeling, and Dietary Supplements. P. 1-34.

36. AHA dietary Guidelines, revision (2000). A statement for health care professionals from the nutrition committee of the American Heart Association. Circulation 2000. 102(18), 2284-99.

37. Joint FAO/WHO Expert Consultation on Fats and Fatty Acids in Human Nutrition (2009). Annals of Nutrition \& Metabolism, 55(1-3), 1-308. 